\title{
Competence-based approach to a module design for the Master Degree Programme in Translation: Challenge of Tuning Russia Tempus Project ${ }^{1}$
}

\author{
Vera Zabotkina, Marina Korovkina, and Olga Sudakova*
}

doi: http://dx.doi.org/10.18543/tjhe-7(1)-2019pp67-92

Received: 1 April 2019

Accepted: 24 June 2019

\begin{abstract}
The article demonstrates the application of the modular competencebased approach for the design of a Master degree programme in translation studies. The case study is based on output materials produced during the lifetime of the Tuning Russia project involving a number of Russian universities, one of which is the Russian State University for the Humanities (RSUH). The module in question - the LSP (language for special purposes) translation module - emphasizes interaction between the related disciplines on the basis of the common subject-matter, i.e. the translation of special purpose texts. The modular approach sets out to achieve key competences required for professional qualifications. In addition, the module considers teaching methods, ECTS and assessment tools. Attention is given to the concept of competencebased approach in contemporary education. The authors argue that the competencebased approach introduced in Russia at the national (Ministerial) level in 2016 facilitates Russia's interactive alignment with the main principles of the Bologna Process adopted by the European Higher Education Area.
\end{abstract}

Keywords: translator training in Russia; learning outcome; competence; module; master degree programme.

*Vera Zabotkina (zabotkina@rggu.ru) is Vice-Rector for International Cooperation, Director of the Centre for Cognitive Programs and Technologies, and Professor at the Department of Translation Studies of the Russian State University for the Humanities (RSUH), Russia. Olga Sudakova (olgsud@yandex.ru) is a professor at the same Department of Translation Studies, while Marina Korovkina (mekorovkina@gmail.com) is a senior lecturer teaching translation and interpreting at Moscow State Institute for International Relations (MGIMO University), Russia.

More information about the authors is available at the end of the article.

Acknowledgements: We are grateful to Dr. Victoria Kruglyakova who contributed to the article at the initial stage of its preparation.

1 This article was prepared with financial support of Russian Science Foundation grant 17-78-30029. 


\section{Introduction}

With the introduction by the Russian Ministry for Science and Higher Education of new competence-based higher education standards, ${ }^{2}$ the impact of the Tuning methodology on the Russian higher education system has increased considerably. The main emphasis in the new standards is placed on the mechanisms of measuring competences according to different levels of successful mastery. Actually, the new federal standards referred to as ' $3++$ ' (based on Tuning methodology) stand for the alignment of Russian higher education area with the European one.

The break-up of the Soviet Union and the ensuing globalization processes have caused tectonic shifts in post-Soviet higher education. A huge demand for professionals such as translators, interpreters and cross-cultural mediators was born to address the $21^{\text {st }}$ century's need for communication and understanding between countries.

Russia's Institutions of Higher Education (HEIs) have undergone reforms which have led to greater freedom and an awareness of competition. This makes the need to restructure their teaching and learning increasingly pressing. Change and transformation echo the mainstream Bologna Process. The over-all requirement calls for a common higher educational area where compatible degrees and the promotion of academic mobility may be shared between countries. The Tuning Project and specifically the Tuning Russia project has successfully entered this shared educational area. The Tuning has developed into a process and approach to (re-)design, develop, implement, evaluate and enhance the quality of degree programmes and curricula. ${ }^{3}$ Ten Russian Universities were involved in this project. RSUH was piloting the Tuning Russia project in the subject area of Modern Languages (Interpreting and Translation) in the period from 2010 to 2013. This has resulted in effective changes in teaching and learning methodologies in Russian HEIs.

\section{Background information}

Russia's transition to the three-cycle system comprising undergraduate, graduate and doctoral studies makes it necessary to redesign all the existing

${ }^{2}$ Russian Federal State Educational Standards for Higher Education in Linguistics (Master's Level) [in Russian], no. 783 (2016), http://fgosvo.ru/news/4/1890.

${ }^{3}$ Vera Zabotkina et al., Reference Points for the Design and Delivery of Degree Programmes in Interpreting and Translation (Bilbao: University of Deusto, 2013), 12. Please follow the sample citations (Notes and Bibliography) for books: https://www. chicagomanualofstyle.org/tools_citationguide/citation-guide-1.html. 
curricula, as they should be based on continuity and quality assurance. In 2002 a new credit system /ECTS/ was adopted by Russian universities to facilitate the compatibility of Russian university degrees on the international labor market. The credit unit consists of 36 academic hours while an academic hour in Russia is equal to 45 (40) minutes, with a lesson normally lasting 2 academic hours (which is eighty or ninety minutes). A full-time academic year accounts for about 60 credits making the Russian system compatible with the European Credit Transfer System (ECTS). A four-year Bachelor's degree requires 240 credits, a five-year Specialität: 300 credits, while a two-year Master's degree programme requires 120 credits. One credit (36 hours) splits into 14 contact hours and 22 hours of students' autonomous/independent work at the BA level and into 10 contact hours and 26 hours of the autonomous work at the MA level, in keeping with the framework imposed by the federal standards. However, the current federal legislation introduced by the Russian Ministry of Education and Science stipulates only the total number of workload/ECTS for a Master degree educational programme that should range from 25 to 30 astronomical hours, which amounts, for instance, to 36 academic (or 27 astronomical) hours at the Russian State University for Humanities (RSUH), or 34 academic (25 astronomical) hours at the Moscow State University for International Relations (MGIMO-university). The relation between contact hours and students' independent workload is rather flexible, though the abovementioned figures (14 contact hours and 22 hours of autonomous work) are observed by HEIs, as established by the federal standards. The current trend is to increase the number of hours of students' autonomous work, though it cannot be feasible in some subject areas.

The cycle approach to the study programmes and curricula enhances the role of modules as their structural units: the use of modules provides interdisciplinary links and compatibility between curricula and cycle degree programmes. The focus is shifted from the programme contents to learning outcomes, and the teaching-learning process becomes less syllabusdominated and more competence-based. As a result, it is getting more interactive and student-centered or "collaborative, experiential, and learningcentered rather than ... teaching-oriented like the teacher-centered chalkand-talk technique," ${ }^{\prime 4}$ with the teacher becoming a facilitator.

The principles and procedures for designing module programmes for the Russian education system were set out in the works by Oleynikova and

${ }^{4}$ Don Kiraly, "Growing a Project-Based Translation Pedagogy: A Fractal Perspective," Meta 57, no. 1 (2012): 84- 85, https://doi.org/10.7202/1012742ar. 
Muravieva. ${ }^{5}$ In their publications, they explore the significance of developing a module approach in vocational training. The high demand for it owes much to the transfer to a knowledge-based society and new technologies. The authors discuss the issues of the dissemination of the module technologies in international practices and the need to apply them in Russia in order to raise the level of higher education standards in different areas and students' mobility.

The module system puts together related disciplines on the basis of the common subject-matter. This process provides cohesion and consistency of the curricula and cycle study programmes as a whole. Firstly, this approach aides the support of each discipline linked by related subjects to achieve common learning outcomes, which are required for professional qualifications. Secondly, the module autonomy within a curriculum and a cycle degree programme enables students to devise and follow their own learning trajectory. A period of study at partner universities would be desirable, if not mandatory.

The article explains the modular approach through a description of a translation module designed to teach translation by developing professional translator competences at the Master degree level.

Competences play a core role in modern education. It is therefore essential to focus on this subject-matter in greater detail, starting with definitions. In Tuning terminology a competence means a proven ability to use knowledge and skills in one's working, professional and private practices. ${ }^{6}$ The 2009 EMT's framework defines it as "a combination of aptitudes, knowledge, behavior and knowhow necessary to carry out a given task under given conditions." ${ }^{\prime 7}$ In other words, competences can be described as inner resources used by an individual to perform their professional tasks. Though there has been some difference in the definition of the term and notion, the competence-oriented approach has gained ground, and now competences can also be deemed as common reference points for the curriculum design and evaluation as well as for the teaching and learning process. $^{8}$

${ }^{5}$ Olga Oleynikova et al., Module Technologies and the Development of Study Programmes [in Russian] (Moscow: Alfa-M 2010), 4-256.

${ }^{6}$ Raquel Crespo et al., "Aligning Assessment with Learning Outcomes in Outcome-based Education," EEE Education Engineering (IEEE EDUCON Education Engineering, 2010), 1-8.

${ }^{7} \mathrm{https} / / /$ ec.europa.eu/info/sites/info/files/emt_competences_translators_en.pdf.

${ }^{8}$ Robert Wagenaar, "Competence and Learning Outcomes: A Panacea for Understanding the (New) Role of Higher Education?," Tuning Journal for Higher Education 1, no. 2 (May 2014): 291. 
It seems interesting to observe how the competence-based approach has been applied in teaching translation. To start with, the competencebased approach in education and curricula design was actively explored in the Soviet Union in the 1970s. The term competence/competency was primarily used to describe the highest level of professional mastery. Being later influenced by western education methodology, particularly, by the communicative competence model in the second language acquisition developed by van $\mathrm{Ek},{ }^{9}$ this term started to denote the ability to use one's knowledge and skills in a professional setting. As the communicative competence is the corner stone of languaging and mediation, it has been the focus of the teaching-learning process in the second language acquisition. (Mediation is used in two meanings: in a more narrow sense, which stands for cross-cultural mediation relating to translation and interpreting, and in a broader sense when it is used "not just to communicate message, but rather to develop an idea through what is often called 'languaging')." 10 The detailed description of the components of the communicative competence is given in the two guidelines documents: the Common European Framework of Reference for Languages ${ }^{11}$ and the above-mentioned CEFR Companion Volume. ${ }^{12}$ Gradually these guidelines were introduced into the programmes of the key linguistic universities in Russia. Moreover, the CEFR has also been taken into account by the above-mentioned Federal Standards. ${ }^{13}$

By way of reflecting the communicative nature of translation and interpreting, the term communicative competence was introduced into the Soviet translation studies. One of the first models of translation competences was built by Komissarov..$^{14} \mathrm{He}$ put together language, communicative, textbuilding and technical competences and gave a detailed description of the psychological and intellectual qualities and aptitudes of a translator/ interpreter. The language component was connected with the communicative competence, text-building related to the discursive one whereas the

9 Jan van Ek, "Coping," The Language Teacher 1 (1988): 35-40.

10 The CEFR Companion Volume (2018), 33, https://rm.coe.int/cefr-companionvolume0with-new-descriptors-2018/16800787989.

${ }^{11}$ Common European Framework of References for Languages, Council of Europe (2001), https://www .coe.int/en/web/common-european-framework-reference-languages.

12 The CEFR Companion Volume (2018), https://rm.coe.int/cefr-companionvolume0with-new-descriptors-2018/16800787989.

${ }^{13}$ Russian Federal State Educational Standards for Higher Education in Linguistics (Master's Level) [in Russian], no. 783 (2016), http://fgosvo.ru/news/4/1890.

${ }^{14}$ Vilen Komissarov, Theoretic Fundamentals of Translation Teaching Methods [in Russian] (Moscow: Rema, 1997), 37-73. 
communicative competence accounted for the ability to make inferences. It was one of the first attempts made by the Soviet researchers to identify and describe the core competences, though they were defined in somewhat different terms compared to their current usage.

The latest models developed by the Russian researchers use the terminology compatible with that of the European Union. For example, Gavrilenko ${ }^{15}$ designed a translator competence model for LSP translation that also correlates with CEFR. ${ }^{16}$

The fundamental notion of Gavrilenko's model is the communicative competence that consists of linguistic, pragmatic and socio-linguistic components. Another key competence includes the knowledge of the subject-matter of specialised source texts as well as discursive, strategic and IT competences. In other words, the translation competence model proposed by Gavrilenko is composed of the knowledge of specific subject-matters related to the topic of translated texts, the knowledge of culture and specifics of the LSP discourse derived from the source culture. Gavrilenko also highlights the importance of the translator possessing adequate psychological and cognitive capacities and aptitudes, as well as emotional intellect. The model in question is applied to teaching written translation of LSP-texts from a foreign/source language (French) into a target/native language (Russian) (direct translation), as is quite relevant for a work environment of would-be translators.

A recent attempt to design a professional translator competence model was made by Korovkina ${ }^{17}$ in her PhD thesis defended in 2017, with special focus on the core translation competences, such as generic and subjectspecific communicative and cognitive competences which require more time to develop.

It should be noted that the latest translation competence-based models developed in Russia are compatible with the studies conducted by European researchers. Newmark ${ }^{18}$ was one of the first in Europe to develop a comprehensive translation competence model. Other prominent researchers $1-175$.

${ }^{15}$ Natalia Gavrilenko, Teaching LSP-Translation [in Russian] (Moscow: RUDN, 2008),

${ }^{16}$ Common European Framework of References for Languages, Council of Europe (2001). https://www.coe.int/en/web/common-european-framework-reference-languages.

17 Marina Korovkina, "Theoretic Aspects of Sense Modelling in LSP-Translation from Mother Tongue into Foreign Language (on the Basis of Newspaper Texts of Economic Discourse)" [in Russian] (PhD diss., Military University, Moscow, 2017), 30-152.

${ }^{18}$ Peter Newmark, About Translation (Clevedon/Philadelphia/Adelaide: Multilingual Matters, 1991), 184. 
worked along the same lines, ${ }^{19}$ for example, Roberts, ${ }^{20}$ Göpferich,${ }^{21}$ Kiraly, ${ }^{22}$ Malmkjaer, ${ }^{23}$ Neubert, ${ }^{24}$ Schaffner ${ }^{25}$ The researchers have singled out such principal competences as language, textual- discursive, transfer competences and the knowledge of the subject-matter. They also stressed the importance of pragmatic aspects in translation and related skills, for example, the ability to understand the communicative situation which depends on the level of the development of communicative and discursive competences, the knowledge of culture which presupposes the well-developed extra-linguistic competence.

Another important group of researchers - PACTE (Hurtado, Orosco, Fox, Presas, Beeby and others $)^{26}$ - has been carrying out empiricalexperimental research into translation competence and its acquisition in written translation since 1997, and merits special acknowledgments. The Spanish researchers have built an integral holistic translation competence model, which has been adjusted and fine-tuned for more than twenty years. They look into the process of translation through the lens of the interpretative model. ${ }^{27}$ The process of translation consists of three stages: grasping the sense of the source text, deverbalizing it, and, while switching over to the target language, reverbalizing the invariant meaning into the target language-

${ }^{19}$ We do not strictly follow the chronological order.

${ }^{20}$ Roda Roberts, "Compétence du Nouveau Diplôme en Traduction," in Traduction et Qualité de Langue. Actes du Colloque Société des traducteurs du Québec (Québec: Éditeur officiel du Québec, 1984): 172-184.

${ }^{21}$ Susanne Göpferich, "Towards a Model of Translation Competence and its Acquisition: The Longitudinal Study Transcomp," in Behind the Mind: Methods, Models and Results in Translation Process Research, ed. Susanne Göpferich et al. (Copenhagen: Samfundslitteratur, 2009), 12-38.

${ }^{22}$ Don Kiraly, "Towards a View of Translator Competence as an Emergent Phenomenon: Thinking Outside the Box(es) in Translator Education," in New Prospects and Perspectives for Educating Language Mediators, ed. Don Kiraly et al. (Tübingen: Gunter Narr, 2013), 197-224.

${ }^{23}$ Kirsten Malmkjaer, "What is Translation Competence?," Revue française de linguistique appliqué 14, no.1 (2009): 121-134, https://www.cairn.info/revue-francaise-delinguistique-appliquee-2009-1-page-121.htm.

${ }^{24}$ Albrecht Neubert, "Competence in Language, and in Translation," in Developing Translation Competence, ed. Christina Schaffner and Beverly Adab (Birmingham/Amsterdam/ Philadelphia: Aston University, John Benjamins Publishing Company, 2000), 3-18.

${ }^{25}$ Christina Schaffner, "Running Before Walking? Designing a Translation Programme at Undergraduate Level," in Developing Translation Competence, ed. Christina Schaffner and Beverly Adab (Birmingham/Amsterdam/Philadelphia: Aston University, John Benjamins Publishing Company, 2000), 143-155.

26 PACTE, "Acquiring Translation Competence: Hypotheses and Methodological Problems in a Research Project," in Investigating Translation, ed. Allison Beeby et al. (Amsterdam: John Benjamins, 2000), 99-106.

${ }_{27}$ Marianne Lederer, Translation. The Interpretative Model (Manchester: St. Jerome Publishing, 2003), 153-155. 
specific structures. The PACTE competence model includes the following components: bilingual sub-competence (which in its turn encompasses pragmatic, socio-linguistic, textual and lexico-grammatical knowledge in the source and target languages), extra-linguistic sub-competence (made up of encyclopaedic, thematic and bicultural knowledge), the translation knowledge, instrumental and strategic sub-competences. ${ }^{28}$

The PACTE group also makes it a point that inverse translation called into life by pragmatic reasons is viable and relevant, with this position opposed in the past by some mainstream European researchers. For example, Newmark believes that inverse translation can be used only as a teaching/learning device, as texts translated from the mother tongue into a foreign language can never reach the quality of a text produced by a native speaker in his/her native language.$^{29}$ Lederer argues that an inversely translated text can never sound natural for pragmatic reasons, as it is practically impossible to render the expressive function of the text at a high idiomatic level. ${ }^{30}$ So it can be assumed that efforts and resources should not be spent on teaching the inverse translation, as the efficiency of teaching will always fall short. However, the current situation is as follows: if the inverse translation is not taught, the much-needed act of intercultural communication may fail to take place. ${ }^{31}$ In this case, a translated text is assessed in terms of acceptability and quality of translation. Thus, at present the attitude towards inverse translation has undergone significant changes. European researchers have recognized the need to teach inverse translation from rare languages into a foreign language (Slavic languages included) whereas Spanish translation researchers and teachers have always been proponents of inverse translation and its teaching for pragmatic reasons on account of market demands. For example, Beeby ${ }^{32},{ }^{33}$ described the competences needed for the translation from the mother tongue into a foreign language (Spanish - English) and emphasized the comparative and dynamic nature of the

${ }^{28}$ PACTE, "Investigating Translation Competence: Conceptual and Methodological Issues," Meta 50, no. 2 (2005): 609-619, https://doi.org/10.7202/011004ar.

${ }^{29}$ Newmark, About Translation, 50.

${ }^{30}$ Lederer, Translation. The Interpretative Model, 153-155.

${ }^{31}$ Gerard Mcalester, "The Evaluation of Translation into a Foreign Language," in Developing Translation Competence, ed. Christina Schaffner and Beverly Adab (Birmingham/ Amsterdam/Philadelphia: Aston University/ John Benjamins Publishing Company, 2000), 228.

32 Allison Beeby, "Evaluating the Development of Translation Competence," in Developing Translation Competence, ed. Christina Schaffner and Beverly Adab (Birmingham/Amsterdam/ Philadelphia: Aston University, John Benjamins Publishing Company, 2000), 185-199.

33 Allison Beeby, "Genre Literacy and Contrastive Rhetoric in Teaching Inverse Translation," in La Direccionalidad en Traducción e Interpretación - Perspectivas Teóricas, Profesionales y Didáctica, ed. Dorothy Kelly et al. (Granada: Atrio, 2003), 155-166. 
communicative and discursive competences, as the translation process is based on the comparison of grammar, vocabulary, communicative situations and the means of cohesion between the source and target languages. Other researchers also support the need for inverse translation training, for example; Chodkiewicz, ${ }^{34}$ Elamin, ${ }^{35}$ Yuste Frias, ${ }^{36}$ Kelly et al. ${ }^{37}$ Pavlović, ${ }^{38}$ Pokorn $,{ }^{39},{ }^{40},{ }^{41}$ Roiss and Weatherby, ${ }^{42}$ Schjoldager, ${ }^{43}$ Seghiri,${ }^{44}$ Stewart,${ }^{45}$ and Ulrych. ${ }^{46}$

${ }^{34}$ Marta Chodkiewicz, "What Types of Errors Do Undergraduate Make Depending on Directionality?," in Translation and Meaning. New series, volume 2, part 2, ed. Łukasz Bogucki et al. (Frankfurt am Main: Peter Lang, 2016): 191-208.

${ }^{35}$ Saadia Elamin, "Foreign Language Courses for Translation Undergraduates. Adapting to Changes in Translation Directionality - A Case Study: English Grammar for Arabic Students," Forum 14, no. 2 (2016): 239-254, https://doi.org/.10.1075/forum.14.2.04ela.

${ }^{36}$ Jose Yuste Frias, "Didáctica de la Traducción Inversa Español-Francés - El Fin Justifica los Medios," in Estudios sobre traducción - Teoría, didáctica, profesión, ed. Jose Yuste Frias and Alberto Álvarez Lugris (Vigo: Servizo de Publicacións da Universidade de Vigo, 2005), 147170. http://www.joseyustefrias.com/docu/publicaciones/JoseYusteFrias\%202005d.pdf.

${ }^{37}$ Dorothy Kelly, Maria-Louise Nobs, Dolores Sanchez, and Catherine Way, "Reflections on Directionality in Translator Training," Forum 4, no.1 (2006): 57-81. doi:10.1075/forum.4.1.04kel.

${ }^{38}$ Nataša Pavlović, "What Were They Thinking?! Students' Decision-making in L1 and L2 Translation Processes," Hermes - Journal of Language and Communication in Business 44 (2010): 63-87, https://doi.org/10.7146/hjlcb.v23i44.97267.

${ }^{39}$ Nike Pokorn, "Natives or Non-natives? That is the Question: Teachers of Translation into Language B,” The Interpreter and Translator Trainer 3, no. 2 (2009): 189-208, https://doi. org/.10.1080/1750399X.2009.10798788.

${ }^{40}$ Nike Pokorn, "Bilingual Teachers in Translation Courses: An Ideal Situation?," in Translationskultur Revisited: Festschrift für Erich Prunč, (Stauffenburg Festschriften), ed. Nadja Grbić (Tübingen: Stauffenburg, 2010), 245-260.

${ }^{41}$ Nike Pokorn, "Is It So Different? Competences of Teachers and Students in L2 Translation Classes," Rivista Internazionale di Tecnica della Traduzione 18 (2016): 31-48, doi:10.13137/2421-6763/13664.

${ }^{42}$ Silvia Roiss and Joanna Weatherby, "A Need for Reorientation - Creative Strategies for the Teaching of Translation into a Foreign Language," in Translators' Strategies and Creativity, ed. Ann Beylardey et al. (Amsterdam: John Benjamins, 1998), 213-221. https://doi. org/.10.1075/btl.27.29roi.

${ }^{43}$ Anne Schjoldager, "Are L2 Learners More Prone to Err When They Translate?," in Translation in Undergraduate Degree Programmes, ed. Kirsten Malmkjær (Amsterdam: John Benjamins, 2004), 127-149. https://doi.org/.httpdoi:10.1075/btl.59.10sch.

${ }_{44}$ Miriam Seghiri, "El Corpus Comparable para la Didáctica de la Traducción Jurídica Inversa (Español-Inglés)," in Traducir en la Frontera, ed. Susana Cruces-Colado et al. (Granada: Atrio, 2012), 815-830.

${ }^{45}$ Dominic Stewart, "Vocational Translation Training into a Foreign Language," in TRAlinea 10 (2008), http://www.intralinea.org/archive/article/1646http://www.intralinea.org/ archive/article/1646.

${ }^{46}$ Margherita Ulrych, "Teaching Translation into L2 With the Aid of Multilingual Parallel Corpora - Issues and Trends,” Miscellanea 4 (2000): 59-80. 
Unlike Europe, the Soviet/Russian school of translation has always advocated the need to teach inverse translation. Actually, there are some other possibilities to improve the quality of inverse translation, for example, through editing made by a native speaker. Another interesting option was suggested by Semenov, namely, working in translators' tandems, when the working languages of two partner translators are the same, though their mother tongues are different, with a native speaker acting as a consultant when a non-native speaker translates into a foreign language.$^{47}$ The same was suggested by Nida as back as in $1964^{48}$ and Pokorn. ${ }^{49},{ }^{50}$

Moreover, according to some researchers, the global demand is currently growing for LSP-texts translations from different languages into English, and the translation by a non-native speaker together with other non-native speakers facilitates the understanding..$^{51}$

Another important point is that all researchers of the PACTE group are unanimous in their views that the acquisition of translation competence as well as that of the instrumental and strategic ones are crucial in the process of teaching translation, given that all the other competences should be already well-developed (primarily the communicative competence, or bilingual one, as it is called by the group).$^{52}$ In practice, this means that the European researchers in general believe that it is more efficient to teach translation at the level of a Master degree after the communicative or bilingual (language) competence has already been well developed.

The Soviet school of translation used to have a different view on the problem: it recognized that all the competences and sub-competences that set up translation competence could be taught at the same time, and, actually, that was the only possible way to teach translation in the Soviet era. At present these attitudes are undergoing changes in both directions. In Europe

47 Arkadiy Semenov, Theory of Translation [in Russian] (Moscow: Academy, 2013), 138.

${ }^{48}$ Eugene Nida, Toward a Science of Translating: With Special Reference to Principles and Procedures Involved in Bible Translating (Leiden: E.J. Brill, 1964), 1-202.

${ }^{49}$ Nike Pokorn, Challenging the Traditional Axioms: Translating into a Non-mother Tongue (Amsterdam, Philadelphia: J. Benjamins, 2005), 1-161.

${ }^{50}$ Nike Pokorn, "Translation into a Non-mother Tongue in Translation Theory: Deconstruction of the Traditional," in Translation in Context: Selected Contributions from the EST Congress, ed. Andrew Chesterman et al. (Amsterdam, Philadelphia: J. Benjamins, 1998), 61-72.

${ }^{51}$ Basil Hatim, Teaching and Researching Translation (London, New York: Longman/ Pearson Education, 2001), 164.

${ }^{52}$ PACTE, "Results of the Validation of the PACTE Translation Competence Model: Acceptability and Decision- making," Across Languages and Cultures 10, no. 2 (2009): 207230, https://doi.org/.10.1556Acr.10.2009.2.3. 
researchers and teachers are also designing and implementing translation undergraduate degree programmes, as "many advantages are to be gained by shaping all or part of an undergraduate degree specifically to prepare students to enter the translation profession (or other professions in which translationrelated skills are required)." ${ }^{53}$ For example, this is done in Spain, Portugal and Belgium..$^{54}$ In Russia, translation is taught both at an undergraduate and graduate level, in Master degree programmes.

One of the aims of translation research studies is to raise quality of translator training. This is the concern of the Bologna Process as well. The Bologna requirements for translation were set out by the European Master in Translation framework (EMT) in 2009 and 2017. The 2009 EMT $^{55}$ presented them in the shape of a wheel, while the 2017 EMT $^{56}$ re-arranged essentially the same competences in a different format employing the term skills at the same conceptual level as the terms competences, knowledge, and learning outcomes. This terminological variety which is present in the Russian educational usage needs clarification. We have already discussed what is meant by the term competence. Alongside with this term, the Soviet teaching methodology used the terms knowledge, abilities and skills (znaniya, umeniya, naviky) as well. At present these are covered by the term competence, which is perceived as an inner resource required for professional activity (see definitions above). These terms - knowledge, skills and competences - are all used simultaneously, but the term competence has become universally accepted. In accordance with the established tradition in Russia, the term skill is used to stand for a minor sub-concept, which is part of a broader concept of the term competence. This understanding is in line with that of the Tuning methodology: a skill is "an intrinsic part of competence." ${ }^{7}$

The term learning outcome is new for Russia, and has not been used in the Russian HEIs before. We follow the Tuning's definition of learning outcomes as "what students should be able to know, understand,

${ }^{53}$ Kirsten Malmkjaer, ed., Translation in Undergraduate Degree Programmes (Amsterdam-Philadelphia: John Benjamins Publishing Company, 2004), 3.

${ }^{54}$ Michael Bastin, "Translation Schools in Belgium," BeTranslated, last modified May 8, 2017, https://www.betranslated.co.uk/blog/translation-schools-belgium/.

55 Competences for Professional Translators, Experts in Multilingual and Multimedia Communication (2009), https://ec.europa.eu/info/sites/info/files/emt_competences_ translators_en.pdf.

${ }_{56}$ EMT Competence Framework (2017), https://ec.europa.eu/info/sites/info/files/emt_ competence_fwk_2017_en_web.pdf.

${ }^{57}$ Robert Wagenaar, "Competence and Learning Outcomes: a Panacea for Understanding the (New) Role of Higher Education?," Tuning Journal for Higher Education 1, no. 2 (May 2014): 297. 
demonstrate, acquire, perform, and/or feel on completion of a course. They are performance-oriented parameters to measure the anticipated students' achievements." 58 "Learning outcomes indicate the level of competence that is desired and should be achieved. They are, in other words, the specifications of the results and outcomes of a learning process." 59 The introduction of the concept of 'a learning outcome' to the Russian education system proves instrumental for quality enhancement of teaching/learning process.

Another asset of the Tuning methodology is the principle of structuring the competence model on the basis of generic and subject-specific competences including four basic components (cognitive, communicative, socio-economic and methodological ones). This principle was applied to translation and interpretation in the Reference Points for the Design and Delivery of Degree Programmes in Interpreting and Translation (Tuning Russia project)..$^{60}$ The competence model proposed there can be used for designing translation/interpreting curricula and programmes at the Bachelor and Master levels.

\section{Problem}

Here we present the design of an LSP-Translation module for the Master degree in Theoretical and Practical Translation, as little attention, if any, has been given to the modular competence-based approach in design of an LSPtranslation module. The challenge is to do it properly in order to be able to achieve key competences required for professional qualifications. Moreover, the problem is how we can implement in reality the student- or learnercentered approach in teaching translation through competences/learning outcomes-based paradigm.

The module is constructed on the basis of the Tuning methodology. The material described is largely based on the above-mentioned Reference Points for the Design of the Degree Programmes in Interpreting and Translation ${ }^{61}$ in particular, the translation course syllabus offered at the

58 Ahmud Al Husban et al., "Implementing the Competences-Based and StudentCentered Learning Approach in Architectural Design Education. The Case of the T MEDA Pilot Architectural Programme at the Hashemite University (Jordan)," Tuning Journal for Higher Education 4, no.1 (November 2016): 57.

${ }^{59}$ Robert Wagenaar, "Competence and Learning Outcomes," 294.

${ }^{60}$ Vera Zabotkina et al., Reference Points, 70.

61 Vera Zabotkina et al., Reference Points, 70. 
Translation Department, School for Philology and History, RSUH (Moscow). This document published in 2013 in the framework of the Tuning Russia project finalised the joint efforts by a number of Russian universities to lay out a framework for devising degree programmes in the area of translation and interpreting. In addition to RSUH that coordinated the subject area group of modern languages (translation and interpreting), the following four universities were also involved in the design of new degree programmes in T/I: the Moscow State Academy of Business Administration, Udmurt State University, Don State Technical University, Yaroslav-the-Wise Novgorod University under the expert guidance of the University of Deusto, Bilbao, Spain, and the University of Groningen, the Netherlands. The model designed by these four universities has laid the basis for the new Federal Standards 3++ in translation and interpreting. That is why modules implemented at various universities within different cycle programmes are fairly similar to the one described in the article, though each university may have some specifics. For example, MGIMOuniversity master programme focuses on training translators and simultaneous interpreters for international organizations. The Moscow State Linguistic University offers undergraduate and master cycle programmes based on a universalist approach as its graduates are able to work practically in all sectors of the economy. The RSUH's competitive edge has long been in the humanities, that is why its graduates are mostly involved in this sector of the labour market.

As we describe an LSP translation module, we need to say a few words about LSP and LSP translation as such. In the 1970s English linguists coined the term 'Language for special purposes' - LSP (in opposition to the 'Language for general purposes'), which was used to facilitate communication in special areas of human knowledge or subject areas, for example, in technologies, law, finances, management, mass media and others. Khaleeva singled out four major areas of communication related to human activities: a) practical area connected with production of goods, b) daily life, c) spiritual or/and cultural area, and d) political area.$^{62}$ It is only in our daily life or daily routines that we use the language for general purposes, while all other areas of knowledge require LSP. LSP is studied through various methodological approaches, in the framework of the discourse analysis, functional stylistics, text linguistics and some others. Picht and Draskau believe that the function of the special communication

${ }^{62}$ Irina Khaleeva, The Theoretic Basics of Teaching Understanding a Foreign Language [in Russian] (Moscow: Vysshaya shkola, 1989), 5-238. 
is to convey specialised information at various levels of complexity in order to disseminate knowledge..$^{63}$

In translation we have to take into account text functions, the leading function of the LSP texts being denotational or informative. This means that in teaching LSP-translation the focus is made on terms and notions denoted by the terms that belong to a specific subject area. The skopostheory states that translation strategies should take into account the text functions. ${ }^{64,}{ }^{65} \mathrm{Pym}^{66}$ believes that it is easier to translate the informative texts that those belonging to a broad pragmatic context (the term by Givon $^{67}$ ), which are not only informative, but also expressive. Moreover, we argue the possibility of both direct and inverse translation, as there is demand for both directions in Russia, as well as a growing global demand for LSP inverse translation from a mother tongue into English, as it has been stated above.

The choice of this particular module out of the ten constituents of the above-mentioned programme (alongside with such modules as Language Theory (Linguistics), Translation Studies, Area or Country Studies) can be explained by its key role in professional translator training. The objective of the module is to provide a student with knowledge, expertise and skills he or she may need to translate texts relating to different functional styles, at $\mathrm{C} 1$ $\mathrm{C} 2$ level of proficiency (according to CEFR) ${ }^{68}$

It is a prerequisite for the Master Degree applicant to have a language competence at least at the $\mathrm{C} 1$ proficiency level, which is to be upgraded to $\mathrm{C} 2$ upon completion of the course.

According to the Tuning methodology, the initial stage of the degree programme design needs to identify a list of competences the student is supposed to develop, which includes generic and subject-specific competences. The next step is to define inter-related competences that can be

${ }^{63}$ Heribert Picht, Jennifer Draskau, Terminology: An Introduction (Guildford: University of Surrey, 1985), 4-265.

${ }^{64}$ Katharina Reiss, Hans Vermeer, Grudlegung einer Allgemeinen Translationstheorie (Tübingen: Niemeyer, 1984), 5-250.

${ }^{65}$ Christiane Nord, Text Analysis in Translation: Theory, Methodology and Didactic Application of a Model for Translation-Oriented Text Analysis (Amsterdam-New York: Rodopi, 2005), 10-250.

${ }_{66}$ Anthony Pym, Miriam Shlesinger, Zuzana Jettmarova, Sociocultural Aspects of Translating and Interpreting (Amsterdam: John Benjamins, 2006), 5-255.

${ }^{67}$ Talmy Givon, Mind, Code and Context: Essays in Pragmatics (New Jersey: Hillsdale, 1989), 5-456.

${ }^{68}$ Common European Framework of References for Languages, Council of Europe (2001), https://www.coe.int/en/web/common-european-framework-reference-languages. 
built in the framework of a module. In our case, the LSP-Translation module aims to develop the following competences:

- Generic Competence:

- Ability to search for, process and analyze information.

- Subject-Specific Competences:

- Translation competence: ability to translate (primarily meaning transfer phase between two languages) ${ }^{69}$ and localize all basic types of texts, providing comments and references required.

- Pragmatic and Stylistic Adaptation competence: ability to reproduce the multi-layer structure of the source text with the help of the target language stylistic adaptations of various types and the target readeroriented adapting strategy, in accordance with the norms of the target language and the criteria applied to a high-quality translation.

- Socio-cultural and cross-cultural competence: ability to apply and decode socio-cultural information contained in a source text.

- Information Technology competence: ability to use modern ITs to search for information, including terminological databases.

The full list of competences in the Translation Studies subject area is presented in the above-mentioned Reference Points. ${ }^{70}$ One module is to develop from three to five competences. It should be noted that there is no unilateral correspondence between a module and a competence: each competence is not supposed to be developed only within one particular module whereas several modules can build one and the same competence. Some competences can be developed and fine-tuned in the course of the translator's professional life, for example, when he/she acquires knowledge and translation experience in a number of LSP areas.

The Tuning methodology assumes that the competences that a student acquires on completing the module help to identify the list of the disciplines which are to be included in the module. They are called the module's structural units. Here we would like to present an LSP-translation module which encompasses the above four subject-specific competences. The table

${ }^{69}$ EMT Competence Framework (2017), https://ec.europa.eu/info/sites/info/files/emt_ competence_fwk_2017_en_web.pdf.

70 Vera Zabotkina et al. Reference Points, 29. 
below features five obligatory units (disciplines/subjects), their workload in ECTS and academic hours. The corresponding term of studies is also indicated..$^{71}$

LSP-Translation Module Structure

\begin{tabular}{|l|c|c|c|c|}
\hline \multicolumn{1}{|c|}{ Discipline } & ECTS & Term & $\begin{array}{c}\text { Hours } \\
\text { Total }\end{array}$ & $\begin{array}{c}\text { Hours } \\
\text { In Class }\end{array}$ \\
\hline Information Technologies in Translation & 3 & 1 & 108 & 54 \\
\hline Translation of Journalistic Texts & 3 & 1 & 108 & 54 \\
\hline Translation of Official/Legal Documents & 3 & 2 & 108 & 54 \\
\hline Translation of Scientific/Technical Texts & 3 & 2 & 108 & 54 \\
\hline Translation of Financial and Economic Texts & 3 & 3 & 108 & 54 \\
\hline
\end{tabular}

All subjects should be studied in a logical sequence from the first to the third term in order to build the required level of competence. Obviously, the course of Information Technologies in Translation should come first as it provides the basis for other specialized translation courses. The courses offering translation of journalistic, scientific/technical, economic/financial, and legal texts and official documents are supposed to take one term at the minimum or more, if deemed necessary.

Nowadays Russian universities calculate their academic workload both in the ECTS to conform to European universities, and in traditional academic hours, in line with the Federal Standards.

The disciplines in question have a total workload of three credit units (ECTS), or 108 hours. The number of hours and ECTS allotted to each discipline is defined by each individual university. The total number of hours of the MT degree allotted for LSP translation amounts to 410 - 540 hours (which is about 15 ECTS) or even 648 hours (18 ECTS), according to programmes drafted by different Russian universities. This is an approximate total time the students need to study a discipline at the Master level (to build the required skills). The module's practical orientation provides for the student's autonomy, that is why some 30 percent of hours are spent in class (instructor-led), though some programmes provide for a 50/50 split between in-class and individual study.

71 The $4^{\text {th }}$ term is omitted here, as it is supposed to be used for writing an MA dissertation. 
Our choice of the above-mentioned module is justified by the fact that LSP-translation is commonly offered at Master degree programmes in Russia owing to a high demand for this kind of translation.

Literary translation is quite another matter. In the Soviet era both the translated literature and its translation were highly popular, as they opened up new horizons for the Soviet people. Literary translation was taught at universities together with other translation modalities and types. At present Russian universities place emphasis on the LSP-translation for pragmatic reasons. Literary translation is taught at a limited number of universities which possess special resources. One of the key educational centres offering literary translation is the Maxim Gorky Literature Institute in Moscow which teaches at present direct translation from English, Spanish, Italian, German, French, Tatar, Bashkir and other Turkic languages into Russian. In this case, naturally, only one-way direct translation is possible. A course of English-Russian literary translation is also offered at the School for Philology and History at the Russian State University for Humanities where it is taught by well-known professional translators (G. Kruzhkov, A. Livergant). Similar courses have been designed by the Moscow State University and Moscow State Linguistic University, and other wellestablished universities in Russia.

Going back to the LSP translation module, we need to identify the types of work and learning methods that would build the above-mentioned competences in the framework of the module's disciplines. The basic types and modes of teaching are as follows:

1. Lectures: Despite the module's practical orientation, students need to obtain theoretical knowledge, as well as the methodology of working with different types of texts. They also need to be able to edit and search for various information sources. The subject Introduction into Translation is more theory-oriented than other disciplines of the module, with lectures accounting for 15 percent.

2. Practical exercises: They account for the bulk of the hours spent in class aimed at developing written translation skills. In the course of training the students perform translation tasks similar to those they will face in their future work. They also translate texts and do translation exercises resorting to special software (translation memory systems) and professional tools (databases, terminology dictionaries and other diverse tools). Moreover, the students are involved in group discussions aimed at analysing texts and contexts of the source language, selecting the best translation strategies, comparing 
translations and discussing the pros and cons of their classmates' translations, editing translated texts. These activities should account for at least 35 percent of the time spent in class.

3. The student's autonomous work (independent studies): It accounts for more than 60 percent of the total workload. Written translations, search for information through specialized tools and on-line resources are included in their individual work. Group projects are also welcome, when students perform real orders for translation. Such a project-based activity promoted by Kiraly ${ }^{72}$ can be most helpful for translating financial, economic or technical texts which will involve all the translation stages: discussing the volume and methods of work, required resources, deadlines, and handing in the final version of a translated text to the client. Peer review or feedback makes a significant impact in this case. As Kiraly puts it, these activities "would serve as the venues for initiating and pursuing the development of translator sub-competences through first-hand experience, with the support of peers (project team members)." ${ }^{73}$ All this may lead to students' greater autonomy and may "empower them to take responsibility for their own learning, their own sense-making and their own future." 74

Another meaningful method in the student's independent work is a comparative analysis of parallel texts. There are two meanings to this term. The first stands for two absolutely identical texts in A and B languages: the original and its translation. ${ }^{75}$ Another meaning relates to the texts produced by two or even more linguistic communities, which belong to the same subject area or even the same topic. ${ }^{76}$ Working with parallel texts, students compare discursive elements in both languages, the means of cohesion and coherence, discursive markers and connectors, the way the information is presented in the text in terms of the theme and rheme ${ }^{77}$ (or sentence functional

72 Don Kiraly, A Social Constructivist Approach to Translator Education. Empowerment from Theory to Practice (Manchester: St. Jerome Publishing, 2000), 1-207.

${ }^{73}$ Don Kiraly, "Growing a Project-Based Translation Pedagogy: A Fractal Perspective," Meta 57, no. 1 (2012): 84, https://doi.org/10.7202/1012742ar: 84.

${ }^{74}$ Ibid: 84.

75 Arkadiy Semenov, Theory of Translation [in Russian] (Moscow: Academy, 2013), $1-126$.

${ }^{76}$ Susanne Göpferisch, "Paralleltexte," in Handbook Translation, ed. Mary Snell-Hornby et al. (Tübingen: Stauffenburg Verlag, 1999), 184-186.

77 The Russian term for the sentence functional perspective. 
perspective), and the correct usage of terms. This analysis enables the students to use more language-specific and idiomatic means in their own translations. ${ }^{78}$

The assessment of learning outcomes is the cornerstone in translation training. In order to assess the students' knowledge of the discipline and their acquisition of the competences developed on completion of the module, the following assessment tools are used: (a) individual tasks of translating texts of various styles; and (b) registers and genres, group translation projects, presentations offering the analysis and comparison of the available translations, editing the final translation versions, and written exams.

To assess the level of competence mastery and acquisition, many Russian universities, the RSUH being one of them, have adopted the European grading scale. Together with that grading system, Russian universities continue to use the long-established 5-point grading scale, as well as 'pass/no pass' grading options.

The main challenge is how to assess or evaluate a student's translation: what is the weight of a grammar, lexical, and stylistic mistake, or a semantic one causing the distortion of meaning? Each university tends to stick to its own assessment criteria. However, it is obvious that the assessment system should be uniform for the whole translator training area.

Actually, the assessment of students' learning outcomes is a concern of many teachers ${ }^{79}$ (not only of those teaching translation).

This problem requires a special attention and is beyond the scope of the present article. It should be mentioned that solid research studies on translation quality assessment are well under way in Russia. To mention just a few, the recent monograph by Knyazheva ${ }^{80}$ is one of them.

The above case study illustrates the design of one module of the Master degree programme for translator training within the competence-based, student-centered approach. It makes part of the whole study programme and fits in the general set-up, which is instrumental for quality programme design.

${ }^{78}$ Hayeyoung Kim, "Teaching Translation into the Second Language to Undergraduate Students - Importance of Background Knowledge and Parallel Texts,” Forum 1 (2004): 29-29, https://doi.org/.10.1075/forum.2.1.03kim.

79 Anna Serbati and Alessio Surian, "Developing Reflection on Competence-Based Learning: the Russian Experience with the Tuning Approach," Tuning Journal for Higher Education 1, no. 2 (May, 2014): 469.

${ }^{80}$ Elena Knyazheva, Translation Quality Assessment: History, Theory, and Practice [in Russian] (Moscow: Flinta, 2018), 1-248. 


\section{Conclusions}

Given the great impact of Bologna Process on the Russian higher education system, the latter has undergone tremendous changes over the past two decades. With the introduction of the 3-cycle system and competencebased new education standards (3++) at the federal level, modern Russian degree programmes become increasingly compatible with those in EU.

First of all, the above case study which reflects the impact of the Tuning Russia project helps to highlight important methodological issues related to translator training and programme design in Russia. Competences prove to be the cornerstone of contemporary education process. The insight into Russian translator training shows that the competence-based approach, which was discussed as early as the 1970s, has undergone rethinking and has become a major issue for the quality design of a new generation of MA in translation. The analysis of the state-of-the-art in translation training in Europe shows a certain degree of compatibility between Russian and European programmes, with the common denominator being a competencebased approach. Given that a lot of research on translation competences is going on in the EU (e.g., EMT, PACTE) and Russia (e.g., the Tuning Russia project), it is essential that consensus should be finally achieved and some common translation competence-based models developed.

The methodological principles of the competence-based education can be exemplified by the LSP translation module designed for the Master Degree programme. The detailed description of the module based on the Tuning methodology can serve as a possible model to design an EU compatible programme in translation. The module is analyzed according to the competences and learning outcomes to be achieved, workload and schedule, constituent disciplines, learning technologies and teaching methods, tools and competence acquisition/mastery assessment criteria.

One of the challenges is the adequate assessment of students' competences/learning outcomes; this issue is under consideration in the present-day translator training. It is an issue for a separate publication, as it is beyond the scope of this article.

The adequate assessment of students' competences/learning outcomes is part and parcel of translator training, and the unification and uniformity of assessment criteria need to be further coordinated in the global educational area.

Common methodology, principles and approaches facilitate the alignment of the Russian higher education system with the main principles of the Bologna Process. 


\section{Bibliography}

Al Husban, Ahmad, Safa Al Husban, and Yamen Al Betawi. "Implementing the Competences-based and Student-centered Learning Approach in Architectural Design Education. The Case of the T MEDA Pilot Architectural Programme at the Hashemite University (Jordan)." Tuning Journal for Higher Education 4, no.1 (November 2016): 43-98.

Bastin, Michael. "Translation Schools in Belgium." Last modified May 8, 2017 at BeTranslated. https://www.betranslated.co.uk/blog/translation-schoolsbelgium/.

Beeby, Allison. "Evaluating the Development of Translation Competence." In Developing Translation Competence, edited by Christina Schaffner and Beverly Adab, 185-199. Birmingham/Amsterdam/Philadelphia: Aston University, John Benjamins Publishing Company, 2000.

_. "Genre Literacy and Contrastive Rhetoric in Teaching Inverse Translation." In La Direccionalidad en Traducción e Interpretación-Perspectivas Teóricas, Profesionales y Didáctica, edited by Dorothy Kelly, Anne Martin, Marie-Louise Nobs, Dolores Sanchez, and Catherine Way, 155-166. Granada: Atrio, 2003.

Chodkiewicz, Marta. "What Types of Errors Do Undergraduates Make Depending on Directionality?" In Translation and Meaning, edited by Łukasz Bogucki, Barbara Lewandowska-Tomaszczyk, and Marcel Thelen, Volume 2, part 2, 191-208. Frankfurt am Main: Peter Lang, 2016.

Common European Framework of References for Languages. Council of Europe, 2001. https://www.coe.int/en/web/common-european-framework-reference-languages.

Competences for Professional Translators, Experts in Multilingual and Multimedia Communication (2009). https://ec.europa.eu/info/sites/info/files/emt competences_translators_en.pdf.

Crespo, Raquel, Jad Najjar, Michael Derntl, Derick Leony, Susanne Neumann, Petra Oberhuemer, Michael Totschnig, Bernd Simon, Izrael Gutierrez, and Carlos Delgado. "Aligning Assessment with Learning Outcomes in Outcome-based Education." EEE Education Engineering. IEEE EDUCON Education Engineering, 2010: 1-8.

Ek, Jan van. “Coping." The Language Teacher 1 (1988): 35-40.

Elamin, Saadia. "Foreign Language Courses for Translation Undergraduates. Adapting to Changes in Translation Directionality - A Case Study: English Grammar for Arabic students." Forum 14, no. 2 (2016): 239-254. doi:10.1075/ forum.14.2.04ela.

EMT Competence Framework, 2017. https://ec.europa.eu/info/sites/info/files/emt_ competence_fwk_2017_en_web.pdf.

Frias, Jose Yuste. "Didáctica de la Traducción Inversa Español-Francés - El Fin Justifica los Medios." In Estudios sobre Traducción - Teoría, didáctica, profesión, edited by Jose Yuste Frias and Alberto Álvarez Lugris, 147-170. Vigo: Servizo de Publicacións da Universidade de Vigo, 2005. http://www. joseyustefrias.com/docu/publicaciones/JoseYusteFrias\%202005d.pdf. 
Gavrilenko, Natalia. Teaching LSP-Translation [in Russian]. Moscow: RUDN, 2008.

Givon, Talmy. Mind, Code and Context: Essays in Pragmatics. New Jersey: Hillsdale, 1989.

Göpferisch, Susanna. "Paralleltexte." In Handbuch Translation, edited by Mary Snell-Hornby, Hans Hönig, Paul Kussmaul, and Peter Schmitt, 184-186. Tübingen: Stauffenburg Verlag, 1999.

—. "Towards a Model of Translation Competence and Its Acquisition: The Longitudinal Study TransComp." In Behind the Mind: Methods, Models and Results in Translation Process Research, edited by Susanna Göpferich, Arnt Jakobsen and Inger Mees, 12-38. Copenhagen: Samfundslitteratur, 2009.

Hatim, Basil. Teaching and Researching Translation. London, New York: Longman/ Pearson Education, 2001.

Kelly, Dorothy, Maria-Louise Nobs, Dolores Sanchez, and Catherine Way. "Reflections on Directionality in Translator Training." Forum 4, no. 1 (2006): 57-81. doi:10.1075/forum.4.1.04kel.

Khaleeva, Irina. The Theoretic Basics of Teaching Understanding a Foreign Language [in Russian]. Moscow: Vysshaya shkola, 1989.

Kim, Hayeyoung. "Teaching Translation into the Second Language to Undergraduate Students - Importance of Background Knowledge and Parallel Texts." Forum 2, no. 1 (2004): 29-49. https://doi.org/.10.1075/forum.2.1.03kim.

Kiraly, Don. A Social Constructivist Approach to Translator Education. Empowerment from Theory to Practice. Manchester, UK: St. Jerome Publishing, 2000.

— . "Growing a Project-Based Translation Pedagogy: A Fractal Perspective." Meta 57, no. 1 (2012): 82-95. https://doi.org/10.7202/1012742ar.

—. "Towards a View of Translator Competence as an Emergent Phenomenon: Thinking Outside the Box(es) in Translator Education." In New Prospects and Perspectives for Educating Language Mediators, edited by Don Kiraly, Silvia Hansen-Schirra, and Karin Maksymski, 197-224. Tübingen: Gunter Narr, 2013. Knyazheva, Elena. Translation Quality Assessment: History, Theory, and Practice [in Russian]. Moscow: Flinta, 2018.

Komissarov, Vilen. Theoretic Fundamentals of Translation Teaching Methods [in Russian]. Moscow: Rema, 1997.

Korovkina, Marina. "Theoretic Aspects of Sense Modelling in LSP-Translation from Mother Tongue into Foreign Language (on the Basis of Newspaper Texts of Economic Discourse)" [in Russian]. PhD Diss., Military University, Moscow, 2017.

Lederer, Marianne. Translation. The Interpretative Model. Manchester: St.Jerome Publishing, 2003.

Malmkjaer, Kirsten, ed. Translation in Undergraduate Degree Programmes. Amsterdam-Philadelphia: John Benjamins Publishing Company, 2004.

"What is Translation Competence?" Revue Française de Linguistique Appliqué 14, no. 1 (2009): 121-134. https://www.cairn.info/revue-francaise-delinguistique-appliquee-2009-1-page-121.htm. 
McAlester, Gerard. "The Evaluation of Translation into a Foreign Language." In Developing Translation Competence, edited by Chistina Schaffner and Beverly Adab, 229-241. Birmingham/Amsterdam/Philadelphia: Aston University, John Benjamins Publishing Company, 2000.

Neubert, Albrecht. "Competence in Language, and in Translation." In Developing Translation Competence, edited by Christina Schaffner and Beverly Adab, 3-18. Birmingham/Amsterdam/Philadelphia: Aston University, John Benjamins Publishing Company, 2000.

Newmark, Peter. About Translation. Clevedon/Philadelphia/Adelaide: Multilingual Matters, 1991.

Nida, Eugene. Toward a Science of Translating: With Special Reference to Principles and Procedures Involved in Bible Translating. Leiden: E.J. Brill, 1964.

Nord, Christiane. Text Analysis in Translation: Theory, Methodology and Didactic Application of a Model for Translation-Oriented Text Analysis. Amsterdam, New York: Rodopi, 2005.

Oleynikova, Olga, Yulya Konovalova, and Elena Sartakova. Module Technologies and the Development of Study Programmes [in Russian]. Moscow: Alfa-M, 2010.

PACTE. "Acquiring Translation Competence: Hypotheses and Methodological Problems in a Research Project." In Investigating Translation, edited by Allison Beeby, Doris Ensinger, and Marisa Presas, 99-106. Amsterdam: John Benjamins, 2000.

- "Investigating Translation Competence: Conceptual and Methodological Issues.” Meta 20, no. 2 (2005): 609-619. https://doi.org/10.72/02011004ar.

—. "Results of the Validation of the PACTE Translation Competence Model: Acceptability and Decision-making." Across Languages and Cultures 10, no. 2 (2009): 207-230. https://doi.org/.10.1556Acr.10.2009.2.3.

Pavlović, Nataša. "What Were They Thinking? Students' Decision-making in L1 and L2 Translation Processes.” Hermes 44 (2010): 63-87. https://doi.org/10.7146/ hjlcb.v23i44.97267.

Pokorn, Nike. "Translation into a Non-mother Tongue in Translation Theory: Deconstruction of the Traditional." In Translation in Context: Selected Contributions from the EST Congress, edited by Andrew Chesterman, Natividad Gallardo, San Salvador, Yves Gambier, 61-72. Amsterdam, Philadelphia: J. Benjamins, 1998.

. Challenging the Traditional Axioms: Translating into a Non-mother Tongue. Amsterdam, Philadelphia: J. Benjamins, 2005.

—. "Natives or Non-natives? That is the Question: Teachers of Translation into Language B." The Interpreter and Translator Trainer 3, no. 2 (2009): 189-208. https://doi.org/.10.1080/1750399X.2009.10798788.

— .Bilingual Teachers in Translation Courses: An Ideal Situation?" In Translationskultur Revisited: Festschrift für Erich Prunč, (Stauffenburg Festschriften), edited by Nadja Grbić, 245-260. Tübingen: Stauffenburg, 2010.

_. "Is It So Different? Competences of Teachers and Students in L2 Translation Classes.” Rivista Internazionale di Tecnica della Traduzione 18 (2016): 31-48. https://doi.org/.10.13137/2421-6763/13664. 
Presas, Marisa. "Bilingual Competence and Translation Competence." In Teaching Translation in Universities. Present and Future Perspectives, edited by Penelope Sewell and Ian Higgins, 19-33. London: AFLS, 1996.

Pym, Anthony, Miriam Shlesinger, Zuzana Jettmarova. Sociocultural Aspects of Translating and Interpreting. Amsterdam: John Benjamins, 2006.

Reiss, Katharina, Hans Vermeer. Grudlegung einer Allgemeinen Translationstheorie. Tübingen: Niemeyer, 1984

Roberts, Roda P. "Compétence du Nouveau Diplôme en Traduction.” In Traduction et Qualité de Langue. Actes du Colloque Société des traducteurs du Québec. Québec: Éditeur officiel du Québec, 1984: 172-184.

Roiss, Silvia and Joanna Weatherby. "A Need for Reorientation - Creative Strategies for the Teaching of Translation into a Foreign Language." In Translators' Strategies and Creativity. - Selected Papers from the 9th International Conference on Translation and Interpreting, edited by Ann Beylardey, Jana Kralova and Barbara Moser-Mercer, 213-221. Amsterdam: John Benjamins. 1998. https://doi.org/.10.1075/btl.27.29roi.

Russian Federal State Educational Standards for Higher Education in Linguistics (Master's Level) (in Russian), no.783, 2016. http://fgosvo.ru/news/4/1890.

Schaffner, Christina. "Running Before Walking? Designing a Translation Programme at Undergraduate Level." In Developing Translation Competence, edited by Christina Schaffner and Beverly Adab, 143-155. Birmingham/Amsterdam/ Philadelphia: Aston University, John Benjamins Publishing Company, 2000.

Schjoldager, Anne. "Are L2 Learners More Prone to Err When They Translate?" In Translation in Undergraduate Degree Programmes, edited by Kirsten Malmkjær, 127-149. Amsterdam: John Benjamins, 2004. https://doi. org/.10.1075/btl.59.10sch.

Seghiri, Miriam. "El Corpus Comparable para la Didáctica de la Traducción Jurídica Inversa (Español-Inglés).” In Traducir en la Frontera, edited by Susana Cruces Colado, Maribel del Pozo Triviño, Ana Luna Alonso, and Alberto Alvarez Lugrís, 815-830. Granada: Atrio, 2012.

Semenov, Arkadiy. Theory of Translation [in Russian]. Moscow: Academy, 2013. Serbati Anna, Alessio Surian. "Developing Reflection on Competence-based Learning: the Russian Experience with the Tuning Approach." Tuning Journal for Higher Education 1, no. 2 (May 2014): 463-481.

Stewart, Dominic. "Vocational Translation Training into a Foreign Language." In TRAlinea 10 (2008). http://www.intralinea.org/archive/article/1646http://www. intralinea.org/archive/article/1646.

The CEFR Companion Volume, 2018. https://rm.coe.int/cefr-companionvolume0with-new-descriptors-2018/16800787989

Ulrych, Margherita. "Teaching Translation into L2 with the Aid of Multilingual Parallel Corpora. Issues and Trends." Miscellanea 4 (2000): 59-80.

Wagenaar, Robert. "Competence and Learning Outcomes: A Panacea for Understanding the (New) Role of Higher Education?" Tuning Journal for Higher Education 1, no. 2 (May 2014): 279-302. 
Zabotkina, Vera, Ekaterina Kabakhidze, Nadezhda Kotova, Vadim Krakovich, Victoria Kruglyakova, Elena Murugova, Natalya Reingold, Olga Sudakova, and Elena Zhukova. Reference Points for the Design and Delivery of Degree Programmes in Interpreting and Translation. Bilbao: University of Deusto, 2013.

\section{About the authors}

VERA ZABOTKINA (zabotkina@rggu.ru), PhD, is Vice-Rector for International Cooperation, Director of the Centre for Cognitive Programmes and Technologies, and Professor at the Department of Translation Studies at the Russian State University for the Humanities (RSUH). She has expertise in EU project management (Erasmus+, EMA2, EM Joint MAs, Tempus, Council of Europe, UNESCO and UNICEF projects, etc.). She is a Bologna promoter and has experience in developing the university strategy of international cooperation with focus on compatibility of degrees, and curricula development for 2 cycles based on the needs of the labor market. She is a certified Higher Education Reform Expert (HERE) and an Expert of the National Training Foundation. She has expertise in setting up quality assurance system within dual degree programme in the framework of Joint European Tempus Project. Prof. Zabotkina is the editor and one of the authors of the Quality Handbook for Joint International MA Programmes. She was coordinating a group of six universities (subject area group - modern languages, translation) within the Joint Tempus project "Tuning Russia" and has more than 190 publications including 5 monographs and articles on cognitive linguistics and international projects. She is a member of the editorial board of several Scopus journals including Tuning Journal for Higher Education. She teaches a course on Foundations of Cognitive linguistics for translators/interpreters.

OLGA SUDAKOVA (olgsud@yandex.ru), PhD, is a professor at the Department of Translation Studies, Russian State University for the Humanities (RSUH), Moscow (Russia). She teaches Written Translation, International News Translation, and Publicistic Translation (English-Russian). Her research interests include text ambivalence and pragmatics in political discourse translation. She translates for "The New Historical Bulletin", a Scopus-indexed research journal (RSUH). Dr. Sudakova participated in the Tuning Project Russia, being a coauthor of "The Reference Points for the Design and Delivery of Degree Programmes in Interpreting and Translation" (2013).

MARINA KOROVKINA (mekorovkina@gmail.com), PhD, is a Senior Lecturer teaching translation and interpreting at Moscow State Institute for International Relations (MGIMO University). She is a practicing simultaneous interpreter in the following subject areas: economics, finance, legal issues, environmental protection, education, cognitive sciences and linguistics, military and political issues, chemistry, medicine, nuclear industry, and some others. Dr. Korovkina is 
actively involved in research, having published about twenty papers on translation and interpreting. Dr. Korovkina also participates in Russian and European conferences on related topics. She was awarded with the Certificate of Merit by the Ministry for Education and Science of the Russian Federation for her contribution into the training of high-skilled translators and interpreters. Dr. Korovkina has designed a course aimed at developing LSP-translation skills in finance and economics. This course takes into account the differences in the conceptual and language world views of Russian and English. Its upgraded edition is used for the training of simultaneous interpreters at the graduate level. 


\title{
Competence-based approach to a module design for the Master Degree Programme in Translation: Challenge of Tuning Russia Tempus Project
}

\author{
Vera Zabotkina, Marina Korovkina, and Olga Sudakova
}

doi: http://dx.doi.org/10.18543/tjhe-7(1)-2019pp67-92

\section{Copyright}

Copyright for this article is retained by the Publisher. It is an Open Access material that is free for full online access, download, storage, distribution, and or reuse in any medium only for noncommercial purposes and in compliance with any applicable copyright legislation, without prior permission from the Publisher or the author(s). In any case, proper acknowledgement of the original publication source must be made and any changes to the original work must be indicated clearly and in a manner that does not suggest the author's and or Publisher's endorsement whatsoever. Any other use of its content in any medium or format, now known or developed in the future, requires prior written permission of the copyright holder. 